
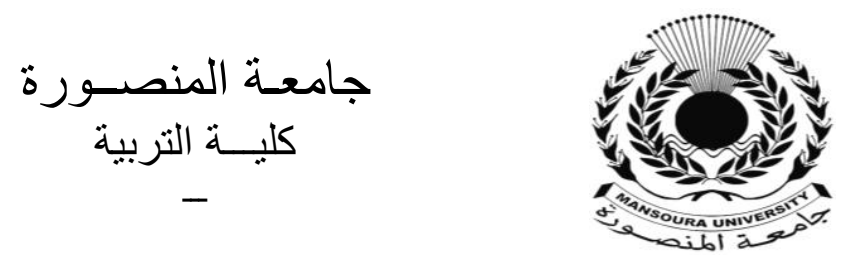

\title{
The Impacts of Globalisation (Technology) on Saudi Culture
}

\author{
By \\ Maisam Abdulrahman yousif \\ Lecturer of the Department of Fundamentals of Education \\ Imam abdulrahman bin faisal university \\ maYousif@iau.edu.sa \\ college of education
}

Journal of The Faculty of Education-Mansoura University

No. 115 - July. 2021 


\title{
The Impacts of Globalisation (Technology) on Saudi Culture
}

\author{
Maisam Abdulrahman yousif \\ Lecturer of the Department of Fundamentals of Education \\ Imam abdulrahman bin faisal university \\ maYousif@iau.edu.sa \\ college of education
}

\begin{abstract}
This study focusses on the challenges that the development of globalisation has brought about in Saudi society. With new technology such as social media programs, there has been social and educational changes in Saudi Arabia. It discusses how cultural globalisation through social media programs have affected Saudi society. This study also discusses theoretical debates that is related to issues in this study. Among debates discussed are: globalisation, homogenous and heterogenous debate, and developing school curriculums. This study examined whether Saudi society has become more homogenous or heterogenous through these changes and to what extent the Saudi educational system has interacted or changed due to forces, in which globalisation has brought. Scholarship, developing curriculums and new vision 2030 consequences of these changes in the educational sector. The findings of this study as there is a widespread adoption of social media programs in Saudi Arabia and this led to some changes in Saudi culture and has causes a gap between the new generation and the old one. Social media affected the Arabic language, in which called Arabizi. Globalisation affected the Saudi educational system by developing school curriculums, and by sending Saudi students to study abroad. The Kingdom of Saudi Arabia has introduced a new a vision 2030 for the educational sector regarding technology and information revolutions.
\end{abstract}

\section{Table of contents:}

Chapter one: The development of globalisation

Chapter two: Background of the Kingdom of Saudi Arabia and its culture.

Chapter three: Challenges facing Saudi Arabia Educational system 


\section{Introduction}

The twenty-first century causes a challenge in the Arab-Muslim world that might influence its future and generations. The Arabs concerned about preserving their Arabica language and their cultural identity in the forces of the west's superiority through globalisation. Saudi Arabia is one of the Arab-Muslim countries that witnesses changes in their society and their educational system as the education plays an essential role in developing the country. Saudi Arabia like many countries has a great transformation from desert country to famous wealthy country. The discovery of oil has significant effects on the economy of the country. Oil wealth one of the main factors of developing the kingdom of Saudi Arabia. Saudi society characterized by having a strong homogeneity, as Al-Farsy (2003) states that the population of Saudi Arabia share the same language which is Arabic, the same religion (Islam) and the same history. In Saudi Arabia Politics, economic and education are specified by the Islamic religion. The economy of the country relies on oil; thus, the welfare system assures free education and health warranty. Wang (2007) states that culture makes people, people make culture, and cultures can be changed due to economic and technological circumstances. The emergence of modernisation affects the Saudi life style. Saudi society influenced by technology revaluation, in particular social media such as Facebook, Snapchat and Twitter. Social media gives the opportunity for international and domestic communications. There are number of specialist in social sector confirmed that some social media programs penetrated of conservative Saudi society. The Arabic language has affected due to social networking program, this led to the appearance of new chat language which call ' Arabizi'. The Saudi educational system has reintroduced and the curricula have been changed to keep up with the development of globalisation and technological revolution. The developing of school curriculums has generate confliction between two streams the first one who are willing to adopt these changes as they believe Saudi education should keep pace with the modern world. The other stream believes that the changes in curricula is due to external demands and these changes will affect their beliefs and traditions. Such a dilemma is influences the new generation.

This study aims to study the impacts of cultural globalisation through social media on Saudi society and whether the Saudi society has become more homogenous or heterogenous, and the effects of globalisation on the Saudi educational system. 
In order to see the impacts of social media on Saudi society and the effects of globalsation on its educational system. Thus, this study will answer the following research questions:

Firstly, how did globalisation through technology particularly social media programs affected Saudi society?

Secondly, have social media programs influenced Saudi social cohesion to become more homogenous or heterogenous?

Thirdly, to what extent the Saudi educational system and its curricula has changed due to globalisation and is 2030 vision for developing the educational sector as a result of globalisation?

\section{CHAPTER ONE}

\section{The development of globalisation}

\subsection{Introduction:}

This chapter gives some definitions of globalisation and a brief history of the development of it. Globalisation has many aspects political, economic and cultural, I will focus on cultural globalisation that takes place through media. This chapter discusses the debate of homogenisation and heterogenisation in reference to media and communication.

\subsection{Detentions of globalisation:}

"Globalisation appears to be the buzz world of the 1990s" (Kellner,2002, p.1). A number of theorists claim that the world is arranged by globalisation, which reinforcement the capitalist economic system and integrating cultures into a global culture (Kellner,2002). Globalisation is seen as a process of spontaneous natural revolution that refers to the gradual interdependence of the world, the revolution of communication that based on the scientific revolution has an affective role (Kellner,2002). Others define "the emergent global economy and culture as a network society grounded in new communications and information technology" (Castells, 1996 cited in Kellner,2002, p.285).

Globalisation has become one of the most controversial issue of the present era (Kellner,2002). For others, globalisation is the post-imperialist global capitalism. Classical liberalism and Marxism both agree that capitalism is a global economic system, and this led to a new modern worldsystem (Kellner,2002).

The first use of the notion globalisation was in publication "Towards New Education" in 1930 (Ruzana,2015). Since the first use of globalisation, the concept of globalisation started to expand and used by sociologists and 
economist (Ruzana,2015). As we live in a period of time is not only a revolutionary but also but also a new stage of transformation which led and will lead to a new structure of the world (Ruzana,2015). Ruzana states that "globalisation seeks feedback between different civilizations and cultures to promote a new international order, which in turn ensure stability, sustainable, development, security and peace" (Ruzana,2015, p.75).

\subsection{The development of globalisation:}

Not only are there debates of the existence of globalisation but there are also arguments of the development of globalisation (Morgan,2001). Globalisation appeared in different ways depending on the period and the place that were held. The main event in 20 century is the development of capitalism, the Russian revolution, the crisis of 1929-1933. As consequences of the World War 1 the greatest crisis of capitalism were slowed by globalisation, after World War 1 capitalism and globalisation have sufferd and also after the Second World war security, stability and peace were came and there were challenges versus capitalism (Ruzana,2015).

It is possible to distinguish three main stages of the history of globalisation to date (Morgan,2001). Firstly, the up growth of a global awareness. Secondly, the prevalence of globalisation (the mid of 19 centuries to the next decade). Thirdly, the increase of global relations from 1960s.

\subsection{Cultural globalisation:}

I would like to start here with different definitions of culture, there is a problem in defining culture as it is contested concept, thus the best way to identify culture in a basic sense "a way of life" (Hopper, 2007, p.37). The problem is the difficulty to cover the individual experiences of specific cultures, in any cultural group there will be variation in behaviors and ideas considering that representing individual lifestyle as a consequence of different aspects such as class, age and gender (Hopper, 2007).

Wang (2007) states that culture is "total pattern of human behavior and its products embodied in speech, action, and artifacts and dependent upon man's capacity for learning and transmitting knowledge to succeeding generations" (Wang,2007, p.84). Culture is seen as a way of life, group of ideas, and ways of thinking and communication(Wang,2007). The world culture can be used in three dimensions, the first one is the relationship between humans, nature and life (the production of goods that they make). The second dimension is related to liturgical which help people to construct 
their community and their relationships. The third dimension is related to religions and ideologies, these three dimensions give to a social group an identity which makes them different from other groups (Wang ,2007). Culture has been seen as an effective and changeable world over time, and recently viewed as process instead of structure or entity (Eriksen,1997, Wilson ,1997).

Culture can be changed depending on people as Wang (2007) states that culture makes people, people make culture, and cultures can be changed due to economic and technological circumstances. Communications technologies helped spread popular cultures. For example, Social media circulated globalised cultures all over the world such as, Facebook and Instagram. Morgan (2001) states that "there has been an important debate about the extent to which globalisation promotes the homogeneity of culture and whether it creates an opportunity for the construction of new forms of hybrid cultures" (Morgan,2001, p.24). Some commentators see that the economy and the media are having a homogenizing influence, and it is claimed that with the improvement of technology and media the world has become smaller and this led to disappearance for some cultures (Hamelink,1983). Globalisation led the world share the same (fast food restaurant, films, brands wear the same style) and this poses a threat on identity or distinctives of cultures.

As a consequence of these improvements it is argued that "cultures and societies are confronted with powerful homogenizing pressures to the extent that it is possible to talk of the existence of global culture, often viewed as a form of cultural imperialism" (Hopper, 2007, p. 88).

\subsection{The relationship between globalisation and culture:}

In the last decades, the relationship between culture and globalisation has become controversial issue, globalisation bother the way that we conceptualize culture (Hopper, 2007). Because of the lack of consensus towards the world culture and what does exactly mean, this makes the relationship between cultures and globalisation quite difficult, cultures are affected by globalisation process and influence by external forces (Hopper, 2007). For example, since 1950s, a number of immigration went to the UK and as a consequence, Britain society has become multicultural society, which has affected its national culture, at the same time there were internal forces within British society such as, women status has changed, and the development of education has influenced British 
national culture (Hopper, 2007). Thus, we cannot argue that culture is constant and it is difficult to have a specific definition.

Wang (2007) suggests that we can see cultural globalisation from another angel, instead of seeing cultural globalisation as threating to existing culture, globalisation can help in creating culture. Wang (2007) argues that "globalisation is not monolith that some argue, and not the uncontrollable force that easily sweeps away other cultures with the dominate culture" (Wang,2007, p.85). Wang (2007) suggests that people themselves have the ability to whether accept or reject cultural globalisation offers. Antiglobalisation proponents argue that the world has become homogenized in the new global era. Consumers of commodities are becoming all over the world homogenous, recently, people use the same goods and things such as, machines, cars and phones (Hopper,2007). Homogenous forced on people by the global market and has become use the same products and goods all over the world (Hopper,2007).In addition, each societies, groups and individuals have their own history and culture, which will form or shape the way that they interact and deal with different aspects of globalisation and to produce deep responses (Hopper,2007). Hopper (2007) states that in terms of individuals their interaction based on different things such as, educational and social background, their knowledge and understanding of globalisation. It is difficult to understand globalisation in abstract way, it should be viewed and experienced in palpable ways. For example,

Understanding cultural globaisation needs us to comprehend the local and global in different contexts, as numbers of people, images, and symbols our localities are permanently changing in contemporary globalisation era, while global communication technology and information as not all people allow to access the global this might causes differential involvement in global, thus it is important to cover this diversity through viewing cultural globalisation in the plural as cultural globalisation (Hopper,2007). It is obvious that when we mention globalisation each approach has different understanding and definitions within academic disciplines. For instance, economists discuss and study globalisation within the global economy and capitalism, whereas, in sociologists globalisation linked to modernity and it relates to global governance in terms of international relations (Hopper,2007). It is important to know that cultural globalisation cannot work in isolation it links to the other dimensions of globalisation. For example, cultural globalisation will be insufficient if it operates without admission for the dominant roles that technology, capitalism, political and sociological analyses that play in cultural 
globalisation, and there is no doubt that capitalism has a strong influence on different dimensions of globalisation containing cultural aspect, and the relationship between cultural globalisation and other aspects not necessarily a direct one (Hopper,2007). Globalisation is not affected only by capitalism but also by technological and scientific development, industrialization, critical thinking and the nation-state, from this perspective globalisation is seen as "a powerful, complex and essentially indeterminate and open-ended transformative force or process responsible for massive change within societies and world order" (Hopper,2007, p.8). As I mentioned above that culture is a dynamic word and it can be changed due to external or internal forces, but the question here how we could maintain our cultural identity in this case? There is no doubt that, each culture has some fixed elements that cannot be changed easily such as religion, language, and history, at the same time there is some changeable elements like habits, food, clothes and art. Although, religion, history and language have some fixed elements, these are never completely fixed. For example, the English language has changed due to the effect of other languages through migration, colonization (French, Latin). Regarding to Hopper (2007) he states that "even a world of motion, cultures are still being reproduced within a myriad of social contexts, providing us with interpretative frameworks, value-system and sources of identity"( Hopper, 2007, p.41). Viewing cultures as shaped by different networks of meaning instead of as characteristic recognizes the varied relationships that people have with cultures, even within one culture the relationship between people and culture is diverse (Hopper,2007).

There are different arguments about globalisation and cultural identities, I will discuss the relationship between cultural identity and globalization in particular, Saudi identity in chapter three.

\subsection{An overview of cultural globalisation:}

It is important to understand how has cultural globalisation started and its origins, there are different phases of cultural globalisation as Hopper (2007) mentioned. The first phase is premodern globalisation and the second one is the modern phase of globalisation, the third phase is the contemporary phase of globalisation.

\subsection{Homogenisation and Heterogenisation argument:}

There are different debates about the cultural impact of global media. Albrow (1996) argues that globalisation led peoples to integrate into a single world society, global society. This causes the argument whether globalisation results in heterogenisation or homogenisation. However, 
Appadurai (1996) has different view from Albrow he asserts that cultural globalisation of media and communications cause separation and complex interaction between cultures. Appadurai (1996) demonstrates five factors that affect culture, and he ensures that these factors cause cultural diversity. These 'scapes' are ideoscapes, technoscapes, finanscapes, mediascapes, and ethnoscapes. Technoscapes refer to technology that pass boundaries and mediascapes point to images and mass media technology. The effects of these scapes lead to cultural disjunctures more than homogenisation. I will discuss how mass media and technology have affected Saudi culture in the third chapter.

Globalisation Leeds to restricting of cultural, political and economic boundaries, in this regard there are two main views. The first view, refers to the process in which the world is becoming comparable due to globalisation (homogenisation). The second view. In which refers to globalisation as heterogenisation process, in this view the world is becoming different. There are a number of debates in the impacts of globalisation regarding to homogenisation and heterogenisation. Giddens (1990) states that the world has become more homogenous with globalisation "creation and intensification of worldwide social relations which link distinct localities in such a way that local happenings are shaped by events occurring miles away and vice versa" (Giddens,1990, p.64). In terms of homogenising and heterogenising process, Waters (2001) states that globalisation "is in general a differentiating as well as a homogenising process... it pluralizes the world by recognizing the value of cultural niches and local abilities" (Waters,2001, p.192). He also argues that globalisation "weaknes the putative nexus between nation and state, releasing absorb ethnic minorities and allowing the reconstitution of nations across former state boundaries" (Waters,2001,192). He also argues that as globalisation obtained from Western modernity, it is possible to have new ethnic identities to cultures, "the vehicles for this cultural flow are electronic images and affluent tourism" (Waters,2001, p.192).

Globalisation has brought tension between globalisation and localisation, or what Robertson (1995) sees globalisation the interaction between local and global process and uses the idea of "glocalisation" to clarify different points about global-local issues. Robertson (1995) states that:

In the prespective of contradiction the tension between, for example, the universal and the particular may be seen either in the dynamic sense of 
being a relatively progressive source of overall change or as a modality which preserves an existing global system in its present state (Robertson,1995, p.33).

Robertson (1995) points out that a sense of the local interaction with the global can be transfer by globalisation, at the local level its values and identities can be protected and at the same time stimulating the local with the global. This is can be connected to the influence of the technology in Saudi Arabia. Technology which considered as a global phenomenon that has infiltrated a local space, Saudi Arabia. The government of Saudi Arabia tries to protect local values by controlling and regulating the uses of the Internet.

From above, technology as a part of globalisation especially, the Internet has major impacts on cultural flows. On one hand, globalisation as a process of making the world homogenous. On the other hand, globalisation as changing socities and providing different views of the world and this lead to a heterogeneous world.

\subsection{Summery:}

Cultural globalisation is linked to the other dimensions of globalisation, such as, economic, political, technological aspects and we cannot understand cultural globalisation in isolation from the other dimensions. There are arguments regarding the beginning of the globalisation and its origins, the difference over the definitions of globalisation it can be considered due to the different understanding of the history of globalisation, different cultures and histories as well.

\section{CHAPTER TWO}

\section{The impacts of globalization (technology) on Saudi's culture}

\subsection{Introduction:}

In this chapter, I will attempt to sketch the effects of cultural globalization through technology positively and negatively and whether Saudi society has become more homogenous or heterogenous. Despite the fact that cultural globalization might be the most dangerous factor that it touches the basis of the culture of any society which includes the language, religion and its traditions. It seems to me at the beginning that it is difficult to find benefits from cultural golbalisation especially, in a such conservative country but I will see it from different angel. As I have mentiond before, the most influential aspect on cultural globalization is the technology revolution, thus I will focus on how technology in particular social media is 
affecting Saudi's culture and its Arabic language. Hopper (2007) states that "the rapid spread of ICTs especially the Internet is making it extremely difficult, if not impossible, for Islamic regimes to control the flow of information into their countries" (Hopper,2007, p.150). There is no doubt that technology and social media has made the communication between people easier all over the world.

Through technology such as the Internet, the world has become like a small village as Mcluhan (1989) stated and he argues that due to the speed of the electronic media that enable us to share and deal with global issues at the same time as if it face to face communication. With the spread of social media program now people can see and hear events that it is far away in distance in seconds, and sometimes even faster of events in our country.

addition, social media helps people to share knowledge and exchange messages. Intercultural adaptation includes the process of understanding other cultures through interaction (Sawyer,

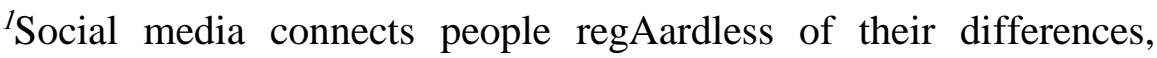
beliefs and their individual traditions. Chen (2012) states that "The compression of time and space, due to convergence of new media and globalisation, has shrunk the world into a much smaller interactive field" (Chen, 2012, p.11). In social media people have the opportunity to express their opinions and critique others in public (Sawyer, 2011). Users' communication and behaviours could be shown clearly through social media. Rosen et al. (2010) state the differences in individualistic and collectivistic cultures. People from individualistic cultures tend to meet new people instead of preserving existing relationships, while people from collectivistic cultures like to maintain their relationship with a small number of ties instead of creating new relationships. Indeed, I think there are some societies concentrate on acting as individuals instead of members of groups and individuals should be free from the constraints of society. While, there are some societies keen on integrating into groups and people feel that they linked to each other through their group. Where would I place Saudi Arabia on this scale? Saudi Arabia is considered as collectivistic culture as Saudis are Muslim and I slam encourages its followers to eat, drink, pray in groups and socialise together, thus, they become as a highly collectivistic culture. However, Islam keen on both individualistic as the individual has a special entity that distinguishes him from others and he is responsible for his 
actions whether they are good or bad. At the same time Islam encourages cooperation with people, take consultations and performance of worship as group.

The spread of social media has affected individual cultures and has promoted the understanding of different cultures, helping them to become more recognisable globally (Sawyer, 2011). For instance, one of the most influential social media programs is Facebook. Facebook was created in 2004 by Mark Zuckerberg and his mission is to give the chance for people all over the world with different backgrounds to communicate with each other and exchange information (Sawyer, 2011). There are about two billion users with different identities in the world using Facebook in 2017 (Newsroom,2017). It has been argued that these kinds of social media programs help people with low self-esteem to improve their psychological well-being through their interaction with people (Sawyer, 2011). The most popular social network in Saudi Arabia after YouTube is Facebook there are 57 percent of Saudi population using the Facebook in 2016 (Anon, 2017). Social media helps people to see themselves from another angle, and sometimes it would be helpful to motivate people in achieving their goals.

Social media has significant impacts on Saudi society, according to Al-Saggaf in his study on the Effect of Online Community on Offline Community in Saudi Arabia there are different positive impacts of the Internet on Saudis, he found that Saudis has become open-minded. The purpose of his study was for understanding the effects of online communities on Saudis. He used online semi-structured interviewing, silent observation of an online community for a year and face to face semistructured interviews. The sample contained 7 males and 8 females with different ages between 15 and 45, different educational levels and different employment status. Online community has helped Saudis to accept and respect other people's views and listen to them without forcing their ideas. In addition, the study assured that social media has changed Saudi thinking and has made individuals to "challenge different ideas" and to make an environment which they can "exchange intellectual discussions". Discussing social problems on social media has made both females and males feel appreciative of one another (Al-Saggaf,2004). Al-Saggaf found in his study that Saudis by using social media "became more self-confident". As in Saudi culture it is common that older people have the priority to express their opinion and in face to face conversation, thus, young Saudi individuals asked not to talk in the presence of elders, therefore, this resulted on younger to become less confidant in themselves. However, the Internet and 
social media gave Saudi's children the chance and the freedom to express their voice and their ideas in public. Nowadays, it has become acceptable for young to express their opinion or disagree with someone's opinion; whereas, in the past it was unacceptable (Al-Saggaf,2004). In the past, some serious discussion might end up with fights, but with social media programs people can discuss different issues and topics and raise their voices freely. Mcluhan states that:

We live mythically and integrally in the electric age, when our central nervous system is technologically extended to involve in the whole of mankind and to incorporate the whole of mankind in us, we necessarily participate ... in the consequences of our every action (Mcluhan,1964, p.4). I think the results of Al-Saggaf study should include quantitative method with a large sample size in order to have better generlisation.

\subsection{The negative impacts of globalisation on Saudi's culture:}

Technology revolution has brought dilemmas to cultures, its global homogenisation affect countries by trying to maintain their cultures, values, language and identity, I will explore the impacts of technology as it is part of cultural globalization on Saudi culture.

The main drawbacks of globalisation as Burbules and Torres (2000) state that "the most obvious 'evils' of globalisation are structural unemployment, the erosion of organized labor as a political and economic force, social exclusion, and an increase in the gap between rich and and poor within nations and, especially worldwide" (Burbules and Torres,2000, p.17). Cultural globalisation has brought challenges and has become as a threat tool for a number of cultures. The main challenges are on language, identity and religion; thus, we want to explore what globalisation has generated in Saudi society regard with Arabic language.

${ }^{1}$ In the last decade, the world has changed significantly through technology and social media. It is clear to see how external forces have affected our self-identities and may shape our self-identity (Belk, 2013). Social media has converted our self-identities from what we want and what we love to "what do people think about me?" and "how can I grab other people's attention through my profile?" (Belk, 2013). The main problem is

${ }^{1}$ This section is taken from my assignment Theoretical Foundations of Educational Ideas 2016/17, title: Provide a brief account of the development of the idea of the politics of recognition. Assess the power and importance of this idea, but also consider its potential problems, page 11 and 12 . 
that self-identities are shaped by the dominant culture and their interests instead of the good and importance of our self-identities (Belk,2013). In 2007 ${ }^{1}$ the writer Christine Rosen stated in her article The new Atlantis, "Does this technology, with its constant demands to collect friends and status and perform by marketing ourselves, in some ways undermine our ability to attain what it promises - a surer sense of who we are and where we belong?" (Rosen, 2007, p.19). I believe that the problem is not simple as many people nowadays are tending to create a new identity about themselves. It seems that not only are people abandoning their principles or even habits, but they are also conceding their real self just to create a positive or good image in front of people more than what they really are. For example, one famous Arabic fashionista who became famous through social media was asked whether her life and her character have changed due to social media and the answer was 'Yes, and I miss my self that she has now to act differently and even to wear what people like, not what she likes.' Unfortunately, life has become more complicated than before, and a lot of pressure has increased in peoples' lives because of some social programs such as Instagram and Snapchat, by posting different pictures. Some of them might be fake, not even reflecting the person's life, and then the problem is that people start to compare their life with others, and they think through these pictures that this person lives a perfect life and he does not have any problems, and people then tend to copy this person and try to live others people's lives due to the pictures that he posted on Instagram. These pictures most of the time reflect a totally different life than the reality. This can show that people try to create new identities about themselves, just focusing on people's opinions about them. In this way, I can lose myself and my identity by giving up my interests, choices and my thoughts, just to keep up with people and not to look different from others. If all people try to copy each other and have the same interests and even the same food, sometimes then people will lose their identity and their uniqueness. "I went from being one person with a single name to existing as a number of identities created by me but not always recognisable as me, even

${ }^{1}$ This section is taken from my assignment Theoretical Foundations of Educational Ideas 2016/17, title: Provide a brief account of the development of the idea of the politics of recognition. Assess the power and importance of this idea, but also consider its potential problems.

2 This section is taken from my assignment Theoretical Foundations of Educational Ideas 2016/17, title: Provide a brief account of the development of the idea of the politics of recognition. Assess the power and importance of this idea, but also consider its potential problems, page 11 and 12 . 
myself (Thomas, 2004, p.9). Hine (2002) argues that the creation of a web page 'is made meaningful primarily through the imagining of an audience and the seeking of recognition from that audience' (Hine, 2000, p.136). Taylor (1994) talks about the massive inward turn in European thinking in the $18^{\text {th }}$ century, where people came to think of themselves as beings with inner depth. Taylor (1994) mentioned Trilling's discussion about the modern self, in particular ethnicity. Taylor (1994)

stated the idea of the modern self: "there is a certain way of being that is my way, I am called upon to live my life in this way... if I am not [true to myself], I miss the point of my life" (Taylor, 1994, p.30). It seems that with social media, people's choices and interests depend on other people's opinions and how they appear to people in their profile, regardless of what they really need.

Mcluhan (1989) suggests that we can experience our actions and its effects immediately on a global scale. Mcluhan (1989) states that we are forced to take into consideration our actions that we experience them on a global level not only with our small communities. He writes "As electrically contracted, the globe is no more than a village, electric speed at bringing all social and political functions together in a sudden implosion has heightened human awareness of responsibility to an intense degree" (Mcluhan,1989, p.5).

Each notion has a history and every nation has a unified idea that is mostly sacred whatever the idea, and everyone is committed to preserving that idea and stick to its values, and the constitution of the state -any state- is often derived from the idea, with other factors of unity, religion and language. In terms of the kingdom of Saudi Arabia, was keening on preserve Salafi Creed especially, ancestors and fathers and this is the unified idea which has become the national identity of the state. There is no doubt that each country has its cultural identity that makes it distinctive and different from other identities. The concept of Saudi nationalism has been preserved until the events of September 11,2001, there were attempts from liberal media trying to create a new concept of Saudi identity. The kingdom of Saudi Arabia was exposed external pressure from America not only on the political level but also on the educational level. I will discuss the impacts of globalisation on Saudi educational system in the last chapter. Now I will move to discuss the effects of technology on Saudi culture as I believe that the most influential factor on Saudi's culture and also other cultures. Since the emergence of technical and information revolution and have become an essential part of human lives, technology has caused a stir 
for many sociologists. With technological revolution, the kingdom of Saudi Arabia has changed from being tribe and traditional country to more open country connecting with outside countries.

\subsection{Language:}

The critics of cultural globalisation claim that due to globalisation the world has become more homogenous (technology, culturally, economically) also by sharing ideas and language. The differences between cultures might be lost due to cultural globalisation. For example, language has become a controversial issue as there are some languages being used more than other such as English language has become an international language. Arabic language is very different from English, which used by most technology applications and this might cause misinformation. There is no doubt that in the age of globalization, the English language has become an international language that people in most countries need to learn for keeping up with world. Learning another language helps people to communicate with each other, and also helps to exchange sciences and knowledge. On the other hand, languages are becoming under threat from the dominance of other languages, especially with English everywhere.

Technology has affect Arabic language in different ways. Technology and social media programs, text messaging and chatting are the most popular tools in communication for Arab youth including Saudis and this has led to appearance 'Arabizi' which means using Arabic letters in chat 'Arabic chat alphabet' (Ehteshami, 2007) ${ }^{1}$. Arabic language has 28 letters that contain sounds are not found in English, thus, Arabs tried to create their special written language by incorporating English letters and numbers (Ehteshami, 2007). It is surprising to note how this mixing is used in communication. In 1990s, Internet, cell phones and computers were introduced to the Arab world and most of them had only English letters to communicate with (Ehteshami, 2007). As a consequence, Arabic people tried to use English letters or numbers by using the closest or similar letters to Arabic. Some people call it "Arabizi" and others "Arabish" which refers to "Arabic" the first letters while the last letters refers to "English". (Ehteshami, 2007). To make it clearer I will take an example, the Number 7 in "Arabizi" for the letter ha which corresponds to the letter $\mathrm{H}$ in English, for example,7lal in Arabizi means Halal in English. The number 3 in

${ }^{1}$ It is not clear the origin of this name, and to find out its origin is beyond the scope of this paper. 
Arabizi for the letter ayn that corresponds to the letter A in English, for example, 3abdulrahman in Arabizi means Abdulrahman. The beginning of this "language" was used by Middle East who had studied or lived abroad then it has become popular in Arab society. Despite the fact that Arabic keyboards now is available, there are a number of people prefer using Arabizi or English keyboards instead of Arabic as they consider English alphabet is easier than Arabic (Ehteshami, 2007). In Saudi Arabia, almost each family has at least two smart phones and iPad even for children, it seems that it is now common for a child 7 years old to have a smart phone or iPad and he or she might use them better than their parents. This led to concern parents and teachers due to the popularity of this trend, Arabizi might weaken the Arabic language or might be replaced in the future (Ehteshami, 2007). Renad Ghanem (2011) in an article in Arab News 'Arabizi is destroying the Arabic language', states that "Arabic professional professors from the Arab world consider it a war against the Arabic language to make it disappear in the long run". Thus, Arabizi is threating not only Arabic language but also the national identity. Professor Emerita Aleya Rouchdy (2011) commented on Renad Ghanem's Article that "the survival of standard Arabic should not be of concern to educarors or Arabic linguaphile (Arabiclanguageinamerica, 2017). What should be of concern is twofold: the increasing tendency to use colloquial in some publications, and the lack of appropriate methods in teaching standard". Problems in communication might be as a consequence of language barriers. In fact, globalisation and technology revolution has affected Saudi culture in different ways. Globalisation has added values and habits that contradict with Islamic values and Saudi culture in general. The clothes, food and even life style, there are a number of examples that confirm that Saudi society has influenced due to these changes. For example, it is common now to celebrate birthday parties, which is a new pheromone in Saudi culture that conflicts with Saudi values and the exaggeration in celebration and gifts. Another general example, due to globalisation individual behaviors has changed, people in Saudi Arabia consider the food as a way of socializing where family member eat together in two main meals which is lunch and dinner. However, nowadays with fast-food restaurants where the meal usually designed only for one person, Saudis especially young start to have their food in more an individualist manner rather than collectivist manner as before. These are just few examples of how globalisation has affected Saudi cultures, I will focus on the effects of social media on Saudi culture. 
With the Internet and social media people all over the world can share different pictures, videos and different ideas. I will take Snapchat as an example and how has affected Saudi society. Social media has a great impact on Saudi society. The statistics points that $29 \%$ of Saudi population using Snapchat program (Anon ,2017).

There are Number of specialists in social affairs confirmed that the social network Snapchat has penetrated the privacy of conservative Saudi society, and there is no longer any privacy in the context of families that document their personal accounts in social sites (Gunter and Eareshi,2016). The public relations and media specialist Tayseer Al-Mufraj (2015) and he is one of the users of this application for cognitive purposes states that the purpose of this program is to enhance the dorms of social communications between friends, relatives and families and transfer knowledge and media coverage of events. He also states that the negative impacts of this program in Saudi society is more than its positive, as the main purpose of this program is to communicate with friends but unfortunately there are many people that they use it for trivial purposes and making clowns and turning them into role model people. Tayseer Al-Mufraj (2015) says that Snapchat one of the most important cognitive applications that keep the user constantly informed about world events and has become an important tool in marketing and advertising products. He confirms that using Snapchat without awareness poses a threat not only on the social level but also on the level of health, behavior and culture, especially that Saudi Arabia ranks second of number of users around the world and the majority of Saudi users between 16 and 20 years old. The tools of social communication in general and Snapchat in particular has caused in a certain category of society the obsession of fame and transformed the aspirations of many of the energies and capabilities of young to a digital ambition that summed up in the number of followers, while the importance not in number, but attention and influence (Gunter and Eareshi,2016). In the past, it was difficult to obtain information about Saudi families because there were barriers that are difficult to penetrate but now it has become easy especially that many Saudi children they use these programs without awareness or supervision from their parents (Gunter and Eareshi,2016). Snapchat has led to family disputes and sometimes lead to divorce because of the comparisons between people. For example, unfortunately many Saudis use this program just for boasting when they go to a high-class restaurant or hotel and take photos just for showing off or when they buy very expensive brands. Indeed, I think this led to social differences and cause pressure for many people especially 
parents as they do not want their children to feel deficiency. Not only in daily life but also on the educational level. For instance, it seems that some Saudi children demand their parents to go to international schools or private schools just to prove for their friends or people through the social media programs by taking photos that they can go to the most expensive schools not looking for the quality of education. It seems also that the intellectual and cultural level is deteriorating as the habit or culture of reading books began to fade as the new generation prefer spending their leisure time on social media programs. In Saudi Arabia, the relationships and communication between members and relatives are strong, but it seems that social media causes for Saudis especially for the young type of isolation as they prefer to face their phones instead of people. Since there are not many entertainment options, thus many youngest found it like breather and this might lead to learn immoral values or exposing to brainwashing. They found social media like breather as they have the freedom to express their opinions and write what they wand and communicate without restrictions. The conclusion of the study on The Effect of Online Community on Offline Community in Saudi Arabia that Saudis ignored their family commitments and conversations were reduced between people because of social media programs. The study also found out that they spend most of their time chatting with their online friends more than with their families and friends and more than studying or reading. In addition, "taking into account that family ties and relationships with relatives, according to religion, are very important, participation in online forums could be a danger to the fabric of the family structure" (Al-Saggaf,2004). The study also concludes that Saudis became intellectually muddled or confused that social media has some ideas and views that could be conflicted with their values.

I think there have been some changes and developments in Saudi society, whether in terms of social relations, family or on the behavior of individuals and turned them into consumption behavior and to pay attention more to the appearance more than anything. In the area of social relations between Saudi individuals and their families, in their relations the individualism and the tendency to independence are overcoming precisely with social media programs on both the standard living and economic.

\subsection{Summery:}

Globalisation has affected Saudi culture especially, with technology and social media. Saudis have become more open-minded, and gave the young the chance to express their voices freely and this led to increase their 
confidence. However, social media has put more pressure on Saudi society especially on the middle class. It seems technology and social media programs generate a gap between the old generation and the new generation even in the language as the new generation uses Arabizi in which old generation cannot understand it. In this case, globalisation particularly technology has influenced Saudi society to become more heterogenous between old generation and the new one. I think the new generation has become liberal from family's commitment and traditions. It is common in Saudi society that young people take care of their parents when they become older, but it seems with social media the young generation is busy with these programs, in which they cannot look after their parents carefully. With virtual communities that social media, which is affordable for everyone especially young, cause pressure on the parents that it has become difficult to control the information and the values that they acquire through these free programs. I do agree with Appadurai (1996) point of view that the mass media cause cultural diversity more than cultural standardisation. Social media has weakened the communication skills between people as many Saudis especially young Saudis has become physically isolated and this led to family fragmentation.

\section{Chapter Three}

\section{Challenges facing Saudi Arabia Educational system}

\subsection{Introduction:}

The emergence of the phenomenon of globalisation affects the field of education as it affects the economic, political and cultural fields. The education system linked to globalisation through its interaction with the local environment as an extension to the impact of the global system on the systems of one society through the global changes in the politics, economy, technological. It seems that globalisation in Saudi Arabia is seen as the most popular and pressing phenomenon at present, that's put many challenges especially in the educational level. Firstly, I will start this chapter by giving an overview of education policy of Saudi Arabia. Secondly, I will clarify the aims of education system in Saudi Arabia. Thirdly, this chapter will discuss the criticism of the experience of the Ministry of Education in the Kingdom of Saudi Arabia in the field of curriculum building. Fourthly, this chapter will discuss some advantages of the development of curriculums and I will take English curriculum as an example in Saudi Arabi and how it has developed. Finally, this chapter will discuss the scholarships for studying abroad and the 2030 new vision for educational sector. 
To what extent the Saudi educational system has adopted with educational variables that globalisation forces on it? One way to examine the effects of globalisation on education is to place or situate the contemporary debate in a historical scope.

\subsection{Saudi Society:}

It is important to take into consideration the situation and the needs of the society when defining the aims of education. The society in Saudi Arabia is strongly affected by Islam, thus it is considered as a highly conservative culture. As a part of the world the kingdom has to interact with the rest of the world, so the education policy maker must consider what goes in the world around the kingdom (Al-Aqeel,2005). It is a very rapid changing world that it is characterised by science, technical, and information revolution and the fast communication and the quick move of people and ideas (Al-Aqeel,2005). As a result, the policy maker in the kingdom realised the importance of the needs for Saudi students.

The aims of education are comprehensive and diverse, and these goals emerge from philosophy of Saudi education that based on Islam (AlAqeel,2005). Education policy in the Kingdom of Saudi Arabia is part of the public policy of the country, policy of education came from official document that contained general principles, objectives for each stage plans, curricula and educational methods (Al-Aqeel,2005).

These goals divided into three sections cognitive, professional, and affective objectives. The cognitive goals confirm that students have enough information and experiences that make them active members in society. In addition, cognitive aims encourage students to computational skills, research and thinking skills, it also promotes the students to study foreign languages beside the Arabic language and to study the Islamic and Saudi history (Al-Aqeel,2005). While, the professional goals concentrate on vocational education that provide students awareness of professions and crafts. In terms of the affective objectives, it encourages students to feel how important is the education for improving societies and help the students to have consciousness of cultural and economic problems. Moreover, emotional aims keen on the psychological growth for students on each stage at schools and ensure helping students to develop spiritual, mental, emotional and social growth (Al-Aqeel,2005). These are the main aims for education in general and a simply way.

As their a kind of globalisation of educational systems there are some common points that all educational systems share all over the 
world(Al-Aqeel,2005). Regardless the nature of the political system, most educational systems all over the world agree on education is right for citizens and the state responsibility is to ensure that everyone has the right to learn (Al-Aqeel,2005). There is a clear tendency to learn foreign languages beside the main language in most educational systems, and the emergence of what we can call it "global education" that help the students to understand the interconnectedness between nations and to a clear vision of economic, political and social problems all over the world (Al-Aqeel,2005). In September 2000 at 'the United Nations' Millennium Summit, world leaders agreed to a set of specific, time-bound and tough targets for intensifying a focused program" the purpose of this program or agenda to disposal of poverty, illiteracy and disease (McDonnell, 2003). The development is in particular for women, primary education, health services and health care, these goals are call 'Millennium Development Goals' (MDGs). "There is increased recognition that just as development cooperation is impossible without common agenda building, and partnership and ownership by 'aid receipt' countries, so too is a global education agenda without partnership with the public" (McDonnell, 2003 p.4)

The question here how to deal with the educational system with these global changes and technical revolution? One of Millennium Development Goals is to achieve international primary education would this be possible?

As I mentioned before, each educational system has aims, objectives, curriculum that reflect society's culture and the educational system will face challenges across these changes especially in education curricula. Information and technical revolution are change and develop rapidly, and to keep pace this development it is important to revise and improve curricula continuously. There will be challenges against the religious and cultural identity, and who should determine the content of curricula? Which social forces can impose their vision on what curricula should contain or change? It is really complicated and difficult question, I will not go in details to answer this question. My question here to what extent the educational system in Saudi Arabia interact with educational changes imposed by the phenomena of globalisation?

The curriculums should concentrate on self-learning principles for students also for the continuous education in order to adapt with cultural variables and give the social role at the best level (Alkhawalda,2007).In addition, the curriculums should focus on how the learner knows not what 
they know. Curriculums should provide the philosophy of knowledge (epistemology) and the historical development and current challenges of human thinking (Alkhawalda,2007). I do agree with Alkhawada point of view about developing curriculums, as we live now in the era of evolution and progress and information and educational theory, which continually be changed and developed, thus, it is important to keep up with these changes and developing curriculums. I think one of the important subjects that need almost yearly to be develop is computer syllabus as technology and its programs are always changed and we cannot wait 5 years for example to develop this curriculum.

The educational systems have been reintroduced and the curricula have been changed to keep up with the cognitive and civilized development of globalisation, which is taking place quickly. Traditional education is not only the resource for knowledge and not only the teacher who can transport the knowledge, now there is different resources with technology that we should prepare students for it.

\subsection{Summery:}

This chapter discussed how the Kingdom of Saudi Arabia keen on developing its education as a result of globalisation and technology to keep up with these changes, and this appears through kingdom's attention to develop curricula, scholarship for students to study abroad and Vision 2030 in the educational sector.

I believe that human societies witness many changes and developments in most fields whether in economic, politics, social and technological aspects. Perhaps the most prominent is technological progress. Saudi society one of many societies that witnesses changes that include cultural changes for many reasons such as scholarships for studying abroad and social media programs. I cannot approve that social media programs such as Facebook, Snapchat or Twitter have completely negative impacts on Saudi society or completely positive impacts. There is no doubt that social media programs have an essential role in activating volunteer work in Saudi society by advertising them through social media programs. In terms of educational

Despite the fact these kinds of social programs help people to communicate with each other all over the world and become more knowledgeable about different cultures, it might affect their cultural identity by acquiring values that conflict with the culture of society. For example, 
some liberal people through these kinds of programs to stir up strife and suspicions about Islam especially for young people.

. In terms of educational aspect Saudi educational institutions try to employ technology in the education process as they believe it attracts students more than traditional means. Globalisation and the openness to the world has brought many changes to Saudi society positively and negatively, 2030 vision prove that many changes will happen in all life aspects especially in the educational sphere.

\section{Conclusion:}

Globalisation is seen as "the emergent global and culture as a network society grounded in new communication and information technology" (Castells,1996 cited in Kellner,2002, p.285). Globalisation affects different factors political, economic and cultural agendas. I focused on cultural aspects as it is the most dangers aspect that it touches language and religion. Culture it is contested concept, thus, the best way to identify culture in a basic sense "a way of life" (Hopper, 2007, p.37). The improvement of Saudi Arabia has been affected by the need to mix modernisation with tradition. Saudi Arabia is the homeland the second largest religion -Islam and the homeland of Arabs. This makes Saudi Arabia a valuable country for many Muslims. Saudi Arabia considered the largest oil export globally. Oil wealth helped to transform Saudi Arabia from desert country to a powerful country. Technology and social media have affected Saudi society positively as the have become open-minded, and gave young Saudis the opportunity to express their voices and opinions freely. Social media helped Saudis to communicate with people all over the world and to know about different cultures. On the other hand, technology revolution such as social media are challenging cultural boundaries. Social media has weakened the communication skills between Saudis especially for young as they became physically isolated and this led to family fragmentation. Globalisation, technology and information revolution has affected Saudi educational system, and causes some challenges to the educational system; particularly, in the curricula. Curriculum is an essential tool for shaping the outputs that society need, if the curricula does meet the need of the society then it would be a gap that weaken the production in general. Developing curriculum on Saudi Arabia received some objection as some people believe that would touch Saudis believe and tradition as they see it is an external force from the western. 
On the other hand, these challenges helped to develop the educational system by the scholarship that the kingdom support for Saudi female and male. In addition, the kingdom of Saudi Arabia has introduced a new vision for the future of the country which is called (Vision,2030) to improve welfare sectors such as education. It plans to improve childhood education and to prepare learners for the job in the futures that correspond with society need. The kingdom of Saudi Arabia aims to refine the national curriculum and to train teachers to keep up with these changes.

\section{References:}

Al-Abbadi, Abd el-Salam (1985). The Islamic Conception of Basic Needs and Its Relationships to Contemporary Conditions": a paper as part of a symposium entitled "Contemporary Social and Economic Conditions and Shapes of Change in in the Islamic World". Oman: The Royal Council of Islamic Civilization.

Al-Gahtani, S. S., Hubona, G. S. and Wang, J. (2007). Information technology (IT) in Saudi Arabia: Culture and the acceptance and use of IT. Information and Management, 44(8), 681-691.

Al-Haqabani, Falih bin Abdalla bin Mohammad (1989). "Factors Determining Consumption in Islamic Economics: A Comparative Study": an unpublished MA Dissertation; Mohammad bin Saud Islamic university, Faculty of Sharia in Riyadh; Department of Islamic Economics.

Al-Hamad, Abdul Aziz Mohammad (1981). "Consumption in Islam": an unpublished MA Dissertation; Umm Al-Qura University; Faculty of Sharia and Islamic Studies; Department of Islamic Economics.

Al-Khayyat, Abdul Aziz (1982). "Development and Luxury from an Islamic Perspective": a research paper presented at a symposium entitled "Islamic Economics"; Oman: University of Jordan.

Al Salloom, H.I., 1989. The system and development of general education and its equivalent programs in the Kingdom of Saudi Arabia. AlMubta'ath.

Al-Aqeel, A. (2005). Education policy and system in the Kingdom of Saudi Arabia. ed. Riyadh: Alrushd.

Albrow, M., 1996. Global Age. John Wiley \& Sons, Ltd

Albugami, S.S. and Ahmed, V., 2015. Towards successful implementation of ICT in Saudi schools (literature review). 
Alessa, A. 2009. Reform education in Saudi Arabia between the absence of political vision and the concern of religious culture and the inability of the educational administration. $1^{\text {st }}$ ed. Lebanon: Dar alsaqi.

Al-Faisal, Turki. "Saudi Education in the Global Community." Town Hall Los Angeles, Los Angeles. 21 March 2006. Available at: http://www.saudiembassy.net/2006News/Statements/SpeechDetail.asp? cIndex $=592$. He repeated the same assurances before the Chicago Council on Foreign Relations and the Economic Club of Chicago, on April 20, 2006

Al-Farsy, F., (2003), Modernity and Tradition: The Saudi Equation, Revised Edition, London: Knight Communications Ltd.

Afar, Mohammad Abdul Moniem (1979). The Islamic Economic System. Jeddah: AlMajmaa Al Ilmi House.

Algamdi,H. and Abduljwad,N. 2010. The development of education in the kingdom of Saudi Arabia.3rd eds. Riyadh: Alrushd.

Alkhawalda, M. 2007. The foundation of building educational curricula and designing the educational book. $1^{\text {st }}$ ed. Amman: Dar Al Masirah for publishing and distribution.

Al-Saggaf, Y., 2004. The effect of online community on offline community in Saudi Arabia. The electronic journal of information systems in developing countries, 16.

Alsaif,M. 1997. Introduction to the study of Saudi society: a curriculum in sociology and functional analysis of society, and scientific lessons in social change and national education. ed. Riyadh: Dar Al-Khuraiji for Publishing and Distribution.

Amara,M (1999). The risks of globalization on cultural identity. Egypt: Dar Nahdet Misr for Publishing and Distribution. p3-43.

Anon, (2017). Saudi Arabia: social media penetration 2016 | Statista. [online] Statista. Available at: https://www.statista.com/statistics/284451/saudi-arabia-socialnetwork-penetration/ [Accessed 17 Oct. 2017].

Appadurai, A., 1996. Modernity al large: cultural dimensions of globalization (Vol. 1). U of Minnesota Press.

Arabiclanguageinamerica.blogspot.co.uk. (2017). Arabizi. [online] Available at: http://arabiclanguageinamerica.blogspot.co.uk/2011/04/arabizi.html [Accessed 14 Oct. 2017]. 
Aramco.jobs. (2017). Our Story - About Saudi Aramco - Saudi Aramco. [online] Available at: http://www.aramco.jobs/AboutSaudiAramco/OurStory.aspx [Accessed 6 Oct. 2017].

Argungu, D. M. (1996). English, Muslims, and Islamisation: Between needs and deeds. English and Islam: Creative Encounters, 96, 331-347.

Belk, R.W., 2013. Extended self in a digital world. Journal of Consumer Research, 40(3), pp.477-500.

Brown, J.D., 2012. EIL curriculum development. Principles and practices for teaching English as an international language, pp.147-167.

Burbules, N.C. and Torres, C.A. eds., 2000. Globalization and education: Critical perspectives. Psychology Press.

Chen, G.M., 2012. The impact of new media on intercultural communication in global context.

Ehteshami, A., 2007. Globalization and geopolitics in the Middle East: Old games, new rules. Routledge.

Eriksen, T.H., 1997. 'Multiculturalism, individualism and human rights: Romanticism, the Enlightenment and lessons from Mauritius', in R.A. Wilson (ed.) Human Rights, Culture and Context, London, pp.49-69.

Fukuyama, F., 1992. The End of History and the Last Man, New York: Free Press.

Giddens, A. (1989), Social Theory and Modern Sociology. Cambridge: Polity Press.

Giddens, A. (1990), The Consequences of Modernity: Cambridge: Polity Press.

Glasser, S.B., 2003. Qatar reshapes its schools, putting English over Islam. Washington Post, 2, p. A20.

Gunter, B. and Elareshi, M., 2016. Social Media in the Arab World: Communication and Public Opinion in the Gulf States. IB Tauris.

Hamelink, C.J. (1983), Cultural Autonomy in Global Communication, London: Longman.

Hine, C., 2000. Virtual ethnography. Sage.

Hopper, P., 2007. Understanding cultural globalization. Polity.

Karmani, S., 2005. English, 'terror', and Islam. Applied Linguistics, 26(2), pp.262-267. 
Kellner, D., 2002. Theorizing globalization. Sociological theory, 20(3), pp.285-305.

Kurian, G.T. (1987), Encyclopaedia of the Third World: New York: Facts on File.

Long, D.E. and Maisel, S., 1997. The Kingdom of Saudi Arabia. Gainesville, FL: University Press of Florida.

Mc Donnell, I., van Harn, P. and Helmich, H., (2003) THE UN MILLENNIUM DEVELOPMENT GOALS.

McDonnell, I., 2003. An international perspective on communication strategies for the Millennium Development Goals. NCDO.

McLuhan, H.M., 1966. Marshall McLuhan. Information Theory, p.234.

McLuhan, M. and Powers, B.R., 1989. The global village. Der Weg der Mediengesellschaft in das, 21.

Ministry of Education (2004). Saudi Arabia's effort in curriculum development (National Report). Oman: Ministry of Education press.

Ministry of Education (2005). English language syllabus. Riyadh: Ministry of Education Press.

Ministry of Information, (2002), Saudi Arabia: Riyadh: Al-Asr for Press and Publishing.

Ministry of Information, (2003), The Information Policy In Saudi Arabia: Riyadh: Al- Asr for Press and Publishing.

Morgan, J., 2001. Development, Globalisation and Sustainability. Nelson Thornes.

Nederveen Pieterse, J. (2004), Globalization and culture, Lanham, MD: Rowman \&Littlefield.

Newsroom.fb.com. (2017). Company Info | Facebook Newsroom. [online] Available at: https://newsroom.fb.com/company-info/ [Accessed 17 Oct. 2017].

Obaid, N., (2001), The Oil Kingdom at 100: Petroleum Policymaking in Saudi Arabia: Washington: Washington Institute for Near East Policy.

Phillipson, R., 2009. Linguistic imperialism continued. Routledge.

Robertson, R., 1995. Glocalization: Time-space and homogeneityheterogeneity. Global modernities, 2, pp.25-45.

Rosen, C., 2007. Virtual friendship and the new narcissism. The New Atlantis, (17), pp.15-31 
Rosen, D., Stefanone, M.A. and Lackaff, D., 2010, January. Online and offline social networks: Investigating culturally-specific behavior and satisfaction. In System Sciences (HICSS), 2010 43rd Hawaii International Conference on (pp. 1-10). IEEE.

Ruzana, M., 2015. History of Globalization. Analele Universitatii" Constantin Brancusi" din Targu Jiu. Serie Litere si Stiinte Sociale, (1), p.75.

Sabic.com. (2017). SABIC - Home. [online] Available at: https://www.sabic.com/en [Accessed 6 Oct. 2017].

Sawyer, R., 2011. The Impact of New Social Media on Intercultural Adaptation. Senior Honors Projects. Paper, 242.

Statistical Year Book, (2002), The Statistical Indicator: Kingdom of Saudi Arabia Ministry of Planning, Issue No.38: Saudi Arabia: Central Department of Statistics.

Statistical Year Book, (2016), The Statistical Indicator: Kingdom of Saudi Arabia Ministry of Planning, Issue No.38: Saudi Arabia: Central Department of Statistics.

Statistical Year Book, (2016), The Statistical Indicator: Kingdom of Saudi Arabia Ministry of Planning, Issue No.38: Saudi Arabia: Central Department of Statistics.

Taylor, C., 1994. Multiculturalism: Examining the politics of recognition, ed. Amy Gutmann.

Thomas, S., 2004. Hello World: travels in virtuality. Sue Thomas.

Thorsen, D.E., 2010. The Neoliberal Challenge-What is Neoliberalism. Contemp. Readings L. \& Soc. Just., 2, p.188.

Turkle, S. (1995), Life on the Screen, New York: Simon \& Schuster.

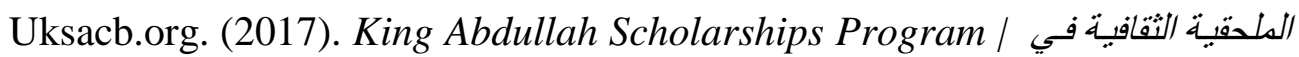
UKSACB. [online] Available at: http://www.uksacb.org/uken1313/page/king-abdullah-scholarships-program [Accessed 8 Oct. 2017].

Vassiliev, A., 2013. The History of Saudi Arabia. London: Saqi.

Vision2030.gov.sa. (2017). Rewarding Opportunities | Saudi Vision 2030. [online] Available at: http://vision2030.gov.sa/en/node/8 [Accessed 7 Oct. 2017].

Wang, Y., 2007. Globalization enhances cultural identity. Intercultural Communication Studies, 16(1), p.83. 
Waters M. (2001), Globalisation, 2nd edition: New York: Routledge.

Wynbrandt, J., 2010. A brief history of Saudi Arabia. Infobase Publishing.

\section{Bibliography:}

Al-Subahi Abdul Hai, A., 1988. A communicative-functional English curriculum for intermediate school in Saudi Arabia: a model for English syllabus design and implementation.

Amine, S. (1996), 'The Challenge of Globalization', Review of International Political Economy,2.

Bennison, A.K., 2002. Muslim universalism and Western globalization. Globalization in world history, 494, p.74.

Castells, M., 2004. Informationalism, networks, and the network society: a theoretical blueprint. The network society: A cross-cultural perspective, pp.3-45.

Elyas, T. and Picard, M., 2010. Saudi Arabian educational history: Impacts on English language teaching. Education, Business and Society: Contemporary Middle Eastern Issues, 3(2), pp.136-145.

Hafez,K (2007), The Myth of Media Globalization, Cambridge: Polity.

Kirchner, H., 2001. Internet in the Arab world: a step towards information society.

Kirkpatrick, D., 2012. The Facebook effect: The real inside story of Mark Zuckerberg and the world's fastest growing company. Random House.

Long, D.E. and Maisel, S., 1997. The Kingdom of Saudi Arabia. Gainesville, FL: University Press of Florida. 